\title{
PHOTOCHEMICAL AND PRODUCTIVE PERFORMANCE OF YELLOW PASSION FRUIT IRRIGATED IN THE BRAZILIAN SEMIARID
}

\author{
Alexson F. Dutra ${ }^{1}$, Alberto S. de Melo ${ }^{*}$, Marcos E. B. Brito ${ }^{3}$, Janivan F. Suassuna ${ }^{4}$, \\ Wellison F. Dutra ${ }^{1}$
}

$2^{2 *}$ Corresponding author. Universidade Estadual da Paraíba (UEPB)/ Campina Grande - PB, Brasil.
E-mail: albertosoares915@gmail.com

\author{
KEYWORDS \\ Passiflora edulis, \\ drought stress, \\ chlorophyll \\ fluorescence, \\ production.
}

\begin{abstract}
The drought stress is an important factor for crops in areas with low rainfall as in the semiarid regions and affects immediately the physiological processes and plant production. However, irrigation is an essential practice to minimize effects of drought stress since the appropriate management is done it can increase the farm income. This study aimed to analyze the photochemical and productive performance of passion fruit (Passiflora edulis) hybrid 'BRS Gigante Amarelo' irrigated in a Brazilian semiarid region. It was studied four water replacement rates $(33,66,100$ and $133 \%$ of ETo) at field conditions. A randomized block design was used with five replications and the fluorescence of chlorophyll $a$, yield and fruit quality were evaluated. The photochemical efficiency of photosystem II has been changed along the day at high temperatures occurring evidential damage in PHS II. Water replacement between 100 and $133 \%$ of ETo $\left(1032 \mathrm{~mm}\right.$ year $\left.^{-1}\right)$ promoted the best production rates and quality of the fruit, however the size of the fruit and bark thickness are reduced by over 100\% ETo.
\end{abstract}

\section{INTRODUCTION}

The Brazilian Northeast is the main producer region of yellow passion fruit, with $71 \%$ of production in Brazil, while productivity $\left(13,559 \mathrm{Mg} \mathrm{ha}^{-1}\right)$ is less than the national average (14,488 $\mathrm{Mg} \mathrm{ha}^{-1}$ ) (IBGE, 2014). In this region due to the intense irregularity in the rainfall distribution, irrigation technique is a practice commonly used in fruit crops, by enabling quantitative and qualitative gains, such as higher levels of productivity, greater uniformity, continuity of production and improvements in the physic and chemical characteristics of the fruits (Freire et al., 2014; Nascimento et al., 2015). However, if used improperly, irrigation can provide damages on production efficiency by drought or excess of moisture to the plants. With this in mind, for best efficiency it is necessary to determine the amount of water to obtain better yields to optimize the irrigation practice and to promote greater economic return.

Water is the most important component for growth and plants development. Excessive water availability causes damages to plants by reduction of aeration in the root zone and cause nutrient leaching. Drought stress may reduce plant growth, physiological metabolism, quality and crops productivity. For that is imperative the appropriate irrigation management in order to improve the water use efficiency and to promote satisfactory plant development (Silva et al., 2015).

Moreover, water changes in the soil cause changes in the plant photosynthetic apparatus and their effects can be verified through chlorophyll $a$ fluorescence by the analysis of the photochemical efficiency of the photosystem II and possible damage occurred due to stress (Suassuna et al., 2011a). This technique has been used in several studies with fruit crops (Suassuna et al., 2011a; Melo et al., 2014), for allowing to analyze the photosynthetic apparatus in the plant, stimulating the assessment of absorption and utilization of light energy by photosystem II and the relationship with the capacity of the photosynthetic apparatus (Suassuna et al., 2011a; Yamamoto, 2016).

Frequent water supply allows the continued flowering and fruiting for passion fruit, making it possible to obtain good yields and fruit quality. External characteristics of the fruits are the main qualitative aspects of evaluation by consumers, which must show desired

\footnotetext{
${ }^{1}$ Universidade Estadual da Paraíba (UEPB)/ Campina Grande - PB, Brasil.

${ }^{3}$ Universidade Federal de Sergipe (UFS)/ Nossa Senhora da Glória - SE, Brasil.

${ }^{4}$ Universidade Federal do Amapá (UFAP)/ Mazagão - AP, Brasil.

Received in: 8-16-2017

Accepted in: 10-23-2018
} 
standards in marketing. The consumer prefers large fruit, good-looking and weighing more than $200 \mathrm{~g}$ (Chagas et al., 2016). The processed market demand is even greater and the fruits must present high pulp yield, high total soluble solids (TSS) and high titratable acidity (TTA) (Aguiar et al., 2015).

Although there are publications on the passion fruit cultivation under irrigated system (Cavichioli et al., 2008; Nascimento et al., 2015; Silva et al., 2016a), it is necessary to obtain information to enable understanding the daily seasonal variability of the fluorescence of chlorophyll $a$ according to irrigation management, which helps identify water replacement levels that affect the photosynthetic apparatus and consequently the fruit characteristics. This study was developed in order to analyze the photochemical and productive performance of the passion fruit hybrid 'BRS Gigante Amarelo' irrigated in the Brazilian Semiarid.

\section{MATERIAL AND METHODS}

\section{Site description and experimental conditions}

The research was performed at the Experimental Area of Fruits and Plant Ecophysiology, Universidade Estadual da Paraíba, Catolé do Rocha - Paraíba, Brazil ( $6^{\circ}$ $21^{\prime} \mathrm{S}$ and $37^{\circ} 48^{\prime} \mathrm{W}$ of Greenwich and $250 \mathrm{~m}$ altitude). According to Thornthwaite (1948), the climate is the $\mathrm{Ds}_{2} \mathrm{~A}$ 'a' type, semiarid with drought stress, average annual rainfall of $870 \mathrm{~mm} \mathrm{yr}^{-1}$ concentrated rainy season between February and April and average temperature of $27^{\circ} \mathrm{C}$.

TABLE 1. Reference Evapotranspiration (ETo), maximum air temperature ( $\mathrm{T}$ max), minimum air temperature (T min), relative humidity $(\mathrm{RH})$, wind speed at two meters from the soil $(\mathrm{S})$, effective precipitation $(\mathrm{P})$ and water level (L) of the experimental area from August 2009 to July 2010.

\begin{tabular}{llllllll}
\hline Month/year & ETo $(\mathrm{mm})^{*}$ & $\mathrm{~T} \max \left({ }^{\circ} \mathrm{C}\right)$ & $\mathrm{T} \min \left({ }^{\circ} \mathrm{C}\right)$ & $\mathrm{RH}(\%)$ & $\mathrm{S}\left(\mathrm{m} \mathrm{s}^{-1}\right)$ & $\mathrm{P}(\mathrm{mm})$ & $\mathrm{L}(\mathrm{mm})$ \\
\hline Aug/09 & $38.3^{* * *}$ & $32.3^{* *}$ & $18.1^{* *}$ & $95.9^{* *}$ & $2.6^{* *}$ & $35.0^{* * *}$ & $3.3^{* * *}$ \\
Sep/09 & 43.7 & 34.7 & 19.2 & 85.9 & 3.3 & 31.8 & 11.9 \\
Oct/09 & 52.1 & 36.1 & 21.0 & 79.7 & 3.7 & 0.0 & 52.1 \\
Nov/09 & 67.4 & 36.4 & 21.8 & 71.6 & 4.7 & 0.0 & 67.4 \\
Dez/09 & 89.9 & 36.0 & 22.5 & 79.8 & 3.5 & 0.0 & 89.9 \\
Jan/10 & 65.0 & 33.7 & 21.8 & 90.9 & 2.1 & 60.2 & 4.8 \\
Feb/10 & 69.9 & 35.4 & 22.6 & 86.7 & 2.7 & 46.3 & 23.6 \\
Mar/10 & 76.7 & 37.3 & 22.7 & 88.3 & 2.6 & 29.5 & 47.2 \\
Apr/10 & 74.0 & 34.1 & 22.4 & 82.1 & 3.4 & 0.0 & 74.0 \\
May/10 & 72.7 & 34.3 & 21.1 & 78.7 & 3.1 & 0.0 & 72.7 \\
Jun/10 & 61.4 & 32.9 & 20.8 & 87.6 & 3.6 & 48.8 & 12.6 \\
Jul/10 & 64.9 & 32.9 & 20.1 & 78.6 & 2.8 & 14.2 & 50.7 \\
\hline Total & 776 & & & & & 265.8 & 510.2 \\
\hline
\end{tabular}

*ETo multiplied by the correction factor due to the location of the water application by the irrigation system forming the wet bulb. $* *$ monthly average. $* * *$ monthly cumulative.

A Fluvisol Eutrophic soil with sandy texture was used (Santos et al., 2013), with the physicochemical analyzes on samples collected at $0.2 \mathrm{~m}$ depth: $\mathrm{pH}\left(\mathrm{H}_{2} \mathrm{O}\right)$, 7.1; P (Mehlich-1), $36 \mathrm{mg} \mathrm{dm}^{-3}$; K, $0.83 \mathrm{cmol}_{\mathrm{c}} \mathrm{dm}^{-3}$; Ca, 2.8 $\mathrm{cmol}_{\mathrm{c}} \mathrm{dm}^{-3} ; \mathrm{Mg}, 0.7 \mathrm{cmol}_{\mathrm{c}} \mathrm{dm}^{-3} ; \mathrm{Na}, 0.16 \mathrm{cmol}_{\mathrm{c}} \mathrm{dm}^{-3} ; \mathrm{Al}, 0.0$ $\mathrm{cmol}_{\mathrm{c}} \mathrm{dm}^{-3} ; \mathrm{H}+\mathrm{Al}, 0.49 \mathrm{cmol}_{\mathrm{c}} \mathrm{dm}^{-3}$; organic matter of 9.54 $\mathrm{g} \mathrm{kg}^{-1}$; bulk density $1.51 \mathrm{~g} \mathrm{~cm}^{-3}$; total porosity, $0.47 \mathrm{~m}^{3} \mathrm{~m}^{3}$; $773.7 \mathrm{~g} \mathrm{~kg}^{-1}$ of sand; $168.3 \mathrm{~g} \mathrm{~kg}^{-1}$ of silt; and $58 \mathrm{~g} \mathrm{~kg}^{-1}$ of clay.

\section{Treatments and irrigation management}

The experiment consisted of four water replacement levels $(33,66,100$ and $133 \%$ of ETo, corresponding to 256 ,

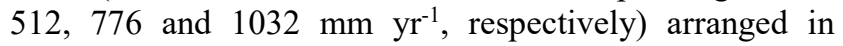
randomized blocks design with five replications and three plants per plot. We used seeds of the hybrid 'BRS Gigante Amarelo' that after seedlings production in the greenhouse, were transplanted in July/2009 to the field in the spacing of $4.0 \mathrm{~m} \times 3.0 \mathrm{~m}$, and the plants conducted by vertical trellis with single strand of wire. Fertilization planting, development and production of passion fruit were based on recommendation by Brito et al. (2005).

The water replacement levels were applied daily beginning 30 days after transplant, period of seedling adaptation. For the application of different water treatment, it was used located drip irrigation system with a flow rate of $4 \mathrm{~L} \mathrm{~h}^{-1}$, varying the number of drippers per plant $(1,2,3$ and
4 drippers for the water replacement 33, 66, 100 and $133 \%$ of ETo, respectively).

Irrigation management was based on climate monitoring and the ETo was calculated by PenmanMonteith [eq. (1)]. Meteorological data were obtained from automated weather station installed near to the experiment.

$$
E T o=\frac{0.408 \Delta\left(R_{n}-G\right)+\gamma\left(\frac{900 U_{2}}{T+273}\right)\left(e_{s}-e_{a}\right)}{\Delta+\gamma\left(1+0.34 U_{2}\right)}
$$

Where,

ETo is reference evapotranspiration $\left(\mathrm{mm} \mathrm{d}^{-1}\right)$;

$\mathrm{Rn}$ is net radiation at the crop surface $\left(\mathrm{MJ} \mathrm{m}^{-2} \mathrm{~d}^{-1}\right)$;

$\mathrm{G}$ is heat flow in soil ( $\left.\mathrm{MJ} \mathrm{m}^{-2} \mathrm{~d}^{-1}\right)$;

$\Delta$ is slope of the vapor pressure curve versus air temperature $\left(\mathrm{kPa}^{\circ} \mathrm{C}^{-1}\right)$;

$\mathrm{U}_{2}$ is wind speed measured at two meters height $\left(\mathrm{m} \mathrm{s}^{-1}\right)$;

$\mathrm{T}$ is temperature $\left({ }^{\circ} \mathrm{C}\right)$;

$\mathrm{e}_{\mathrm{s}}$ is saturation vapor pressure of water $(\mathrm{kPa})$;

$\mathrm{e}_{\mathrm{a}}$ is actual pressure of water vapor $(\mathrm{kPa})$, and $\gamma$ is psychrometric factor $\left(\mathrm{MJ} \mathrm{kg}^{-1}\right)$. 
The gross water level, water application rate and irrigation time were determined using eqs (2), (3) and (4), respectively (Mantovani et al., 2006).

$$
G W L=\frac{E T o . K c \cdot K s-P e}{E f}
$$

Where,

GWL is the gross water level $\left(\mathrm{mm} \mathrm{d}^{-1}\right)$;

ETo is the reference evapotranspiration according to Penman-Monteith $\left(\mathrm{mm} \mathrm{d}^{-1}\right)$;

$\mathrm{Kc}$ is the crop coefficient, adopted 0.5, 0.9 and 1.1 for application of ETo;

$\mathrm{Ks}$ is the percentage of wetted area by the emitter;

$\mathrm{Pe}$ is the precipitation during the period ( $\mathrm{mm})$, and

Ef is the efficiency of irrigation method.

$$
A I=\frac{n \times v}{e c}
$$

Where,

$A \mathrm{I}$ is the application intensity $\left(\mathrm{mm} \mathrm{h}^{-1}\right)$;

$\mathrm{n}$ is the number of emitters per plant;

$\mathrm{v}$ is the emitter flow $\left(\mathrm{L} \mathrm{h}^{-1}\right)$, and

$\mathrm{c}$ is the area occupied by the plant $\left(\mathrm{m}^{2}\right)$.

$$
I T=\frac{G W L}{A I}
$$

Where,

IT is the irrigation time (h);

GWL is the gross water level $\left(\mathrm{mm} \mathrm{d}^{-1}\right)$, and

$\mathrm{AI}$ is the application intensity $\left(\mathrm{mm} \mathrm{h}^{-1}\right)$.

\section{Evaluation of photosystem II}

At 150 days after transplantation, we proceeded to the determination of chlorophyll $a$ fluorescence, assessing the initial fluorescence (Fo), maximum fluorescence (Fm), variable fluorescence $(\mathrm{Fv})$ and quantum efficiency of photosystem II (Fv/Fm) (Murchie \& Lawson, 2013). Readings were taken five times along the day, at 8:00, 10:00, 12:00, 14:00 and 16:00 o'clock in three intermediate leaves of the tertiary branch of useful plants in each plot after being pre-adapted to the dark for 30 minutes, using a portable fluorometer (LI-1600, USA).

\section{Production Evaluation}

It was also evaluated in the first production period ( 8 months after transplantation), fruit weight (FW) $\left(\mathrm{g} \mathrm{fruit}^{-1}\right)$ by weighing the fruit in precision electronic scale; productivity (PD) $\left(\mathrm{kg} \mathrm{plant}^{-1}\right)$; longitudinal fruit diameter (LFD) (mm) and traverse fruit diameter (TFD) (mm) and peel thickness (PT) (mm) using a digital caliper; pulp yield (PY) $(\%)$ and juice yield (JY) (\%), determined by relation between the fruit weight and the mass of the pulp and juice.

\section{Statistical analysis}

The data were submitted to analysis of variance by ' $F$ ' test $(\alpha \leq 0.05)$ and regression models were adjusted according to the coefficient of determination $(\alpha \leq 0.05)$, using the Software SAEG 9.1.

When analyzing the data together it was performed a multivariate study by Principal Component Analysis (PCA), which allows to condense the greater amount of relevant information contained in $p$ variables $(p=11$ in this trial) a lower set of orthogonal latent variables called principal components, which are generated by linear combinations of the original variables from the eigenvalues of the covariance matrix. Each pair of principal components resulted in a biplot, a two-dimensional representation of the space of the original variability. The appropriateness of this analysis is verified by the full information of the original variables held in the main components showing eigenvalues greater than the unit or lower eigenvalues of which do not have the relevant information. Processing of multivariate statistical analysis used the Software STATISTICA.

\section{RESULTS AND DISCUSSION}

\section{Chlorophyll $a$ fluorescence}

The chlorophyll $a$ fluorescence was not significantly affected by irrigation levels, but it was influenced by evaluation period along the day. The water availability by the treatments may have been enough to keep soil moisture required for plants photochemical processes which results in no damage to the protein structures of the photochemical complex of the thylakoids membranes. Under irrigation systems $20-80 \%$ of field capacity, Silva et al. (2016b) showed no change in photochemical parameters in Hancornia speciosa.

The Initial fluorescence (Fo) increased gradually throughout the day, with maximum value (674.15) at 16:00 and an increase of $27 \%$ against fluorescence measured at 8:00 (Figure 1A). This may be related to the increase on air temperature because the maximum temperature reached 36 ${ }^{\circ} \mathrm{C}$ occurred between 13:00 and 16:00, causing a possible thermal stress in plants and an unbalance between demand and water supply by the roots. High temperatures, occasioning stomatal closure and reducing intercellular of $\mathrm{CO}_{2}$ concentration causes changes in the redox properties in acceptors of electrons in the PSII and reduces efficiency of the electrons transport in both photosystems (Mathur et al., 2014). 


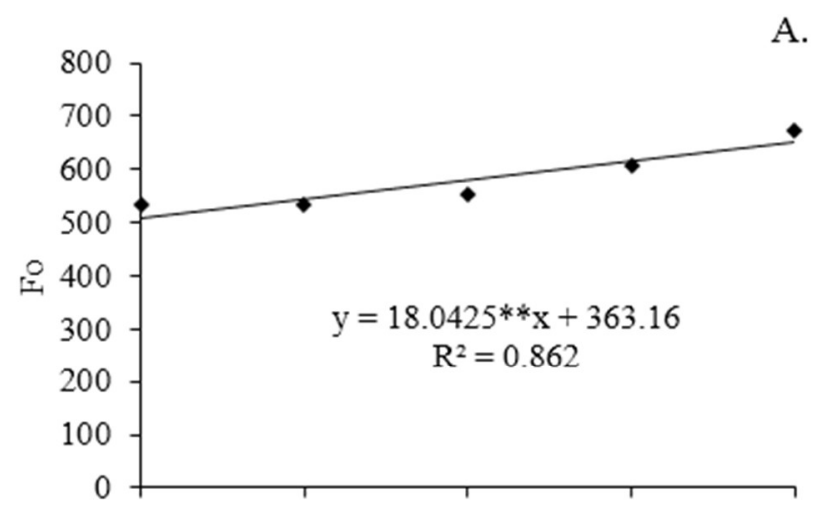

A.

B.
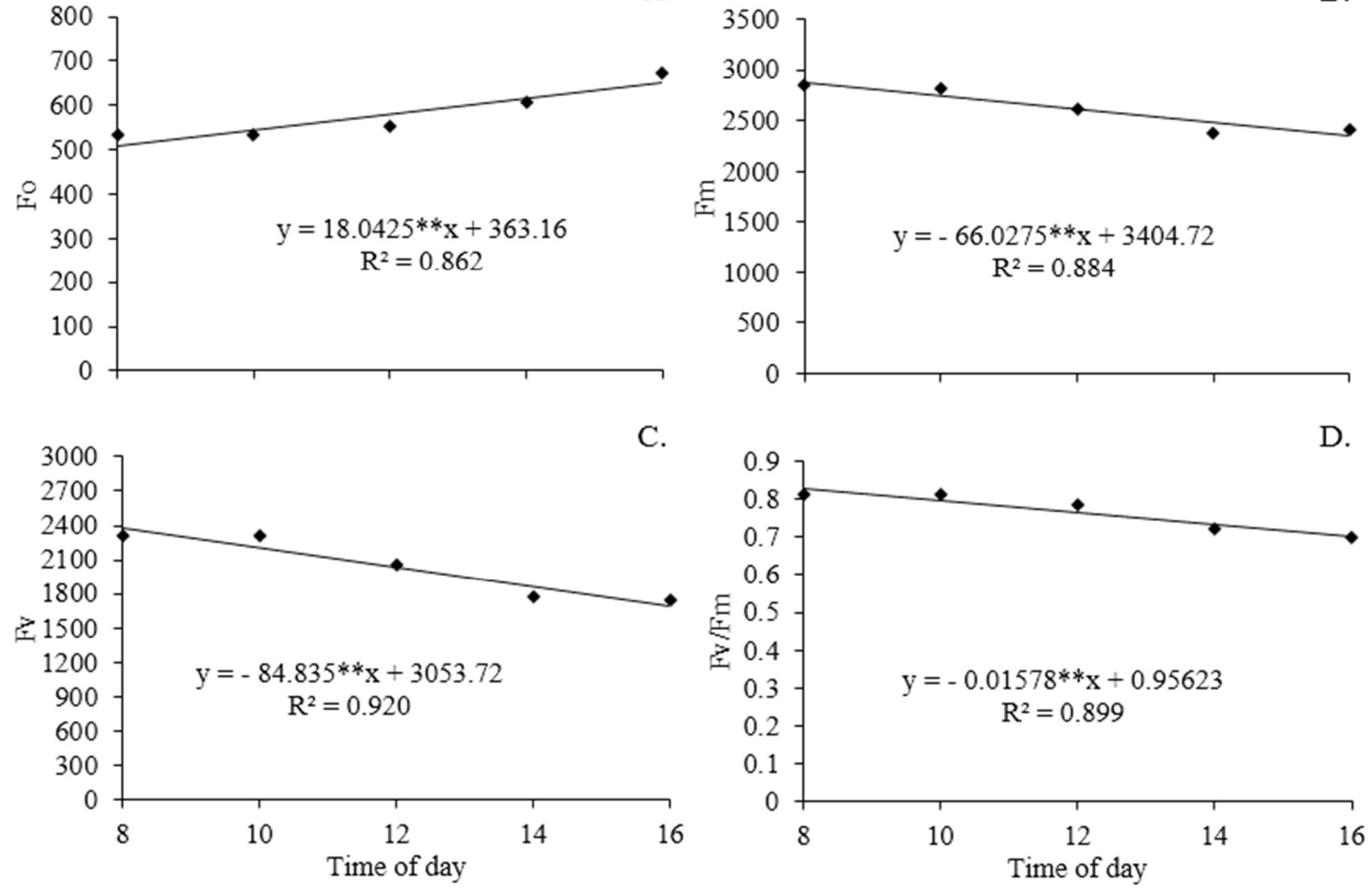

FIGURE 1. Initial fluorescence (Fo) (A), maximum fluorescence (Fm) (B), variable fluorescence (Fv) (C) and photochemical efficiency of PHS II (Fv/Fm) (D) of passion fruit hybrid 'BRS Gigante Amarelo' at different periods of the day.

The Fo represent part of the energy captured by the complex-antenna that was not absorbed by photosynthetic pigments when has high values, reveals damage in the reaction center of PSII $\left(\mathrm{P}_{680}\right)$ or weakening in the transfer capacity of the antenna complex energy to the reaction center (Murchie \& Lawson, 2013). Thus, the increase in Fo may indicates momentary occurrence of complex-antenna dissociation (LHC II) of PSII, inactivation of photochemical reactions in PSII or a brief inhibition of electron flow due to the reduced transfer from quinone $\mathrm{Q}_{\mathrm{A}}$ and $\mathrm{Q}_{\mathrm{B}}$ (Mathur et al., 2014). The results are similar to those obtained in studies with plants subjected to heat treatment, which found an increase in Fo with high temperatures, as noted in tea leaves (Lin et al., 2016) and in wheat crop (Brestic et al., 2012).

Regarding the maximum fluorescence (Fm), it is the state where the PSII reactions centers are unable to increase photochemical reactions by reaching the peak of fluorescence, because all $\mathrm{Q}_{\mathrm{A}}$ is reduced by electrons transferred from the PSII (Murchie \& Lawson, 2013). In the current study, Fm was reduced throughout the day, with decreases around $15 \%$ at 16:00 compared to the results found in the first evaluation time (at 8:00) (Figure 1B). This result may be caused by increasing temperature in the afternoon, promoting possible damage to the electrons transference between complex-antenna and reaction centers, which makes the fluorescence reaches its peak. Therefore, the reduction Fm characterized deficient $Q_{A}$ photo-reduction, which may be associated with inactivation of PSII in thylakoid membranes, directly affecting the electrical flow between photosystems.

The variable fluorescence $(\mathrm{Fv})$ is the variation in between the initial and maximum fluorescence. There was a decreasing trend throughout the day, with values ranging from $2,316.65$ to $1,736.65$ between $8: 00$ to $16: 00$, respectively, showing a reduction of $25 \%$ in the last assessment time (Figure 1C). Similar behavior was observed in the $\mathrm{Fv} / \mathrm{Fm}$, with $14 \%$ reduction in photosystem efficiency at 16:00 (0.699 electron quantum $\left.{ }^{-1}\right)$ when compared to the efficiency obtained at 8:00 (0.811 electron quantum $^{-1}$ ) (Figure 1D). This decrease in $\mathrm{Fv} / \mathrm{Fm}$ ratio according to Brestic et al. (2012) and Mathur et al. (2014) is associated directly with the increase Fo and power dissipation as heat, and with Fm reduction in hightemperature environments. It is noteworthy that in most plants, leaf temperature above $35{ }^{\circ} \mathrm{C}$, the beginning of the reduction in the photochemical efficiency is followed by stimulation with non-photochemical dissipation (nonphotochemical quenching) of the fluorescence of chlorophyll, due to the increase of energy dissipation in heat (Mathur et al., 2014), thus reducing the energy available for photochemical processes.

The quantum yield of PSII between 8:00 and 10:00 was more than 0.8 , attributing this result to higher soil moisture and moderate temperature in this period due low intensity of solar radiation. According to Yamamoto (2016) and Fan et al. (2014), Fv/Fm values less than 0.8 is indicative of photoinhibition in the plants. Thus, leaves of 
passion fruit were slightly photoinibition from 12:00, a condition that has intensified in the afternoon, from 14:00 to $16: 00$. However, this effect is transient, occurring at night recovery of the PSII reaction center, starting thus a new cycle (Paula et al., 2015).

Similar results were reported by Paula et al. (2015) in Vochysia Cimnamonea in the Brazilian cerrado areas, observing $\mathrm{Fv} / \mathrm{Fm}$ values around 0.8 in the leaves analyzed at 8:00, occurring after this time continuous reduction of PSII efficiency. Decrease in the quantum yield of PSII with photoinhibitory effect on plants, was also observed in grape (Silva et al., 2017), wheat (Brestic et al, 2012), in watermelon (Melo et al., 2010) and melon (Suassuna et al., 2011a). These researchers agree that changes in PSII efficiency is a sensitive indicator of the photosynthetic plant performance, being an active physiological mechanism in the presence of intracellular stress.

\section{Multivariate analysis}

In the principal component analysis (PCA) it was observed a better structure way of the variability to fluorescence data in the evaluations periods, so the first two main components comprised $99.89 \%$ of the total variation with $96.14 \%$ of the information contained in the original data were aggregated on the first component (CP1), while the second component (CP2) only $3.75 \%$ of the variability was expressed (Figure 2).

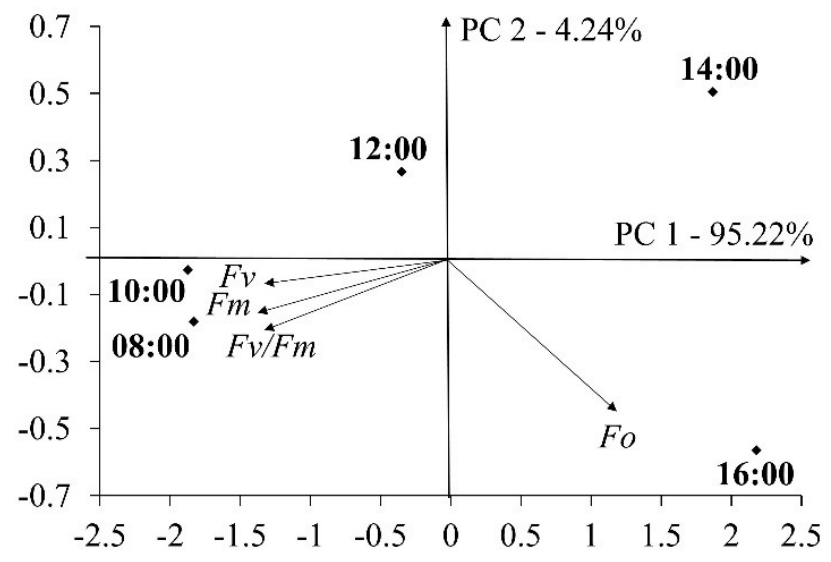

FIGURE 2. Analysis of the first two principal components associated with initial fluorescence (Fo), maximum fluorescence (Fm), variable fluorescence (Fv) and photochemical efficiency of PHS II (Fv/Fm) of passion fruit hybrid 'BRS Gigante Amarelo' at different periods of the day. The percentages correspond to the amount of variability that is explained by the respective component. The proximity of the vectors indicates a strong correlation between the variables.

When analyzing the CP1, which is associated with the chlorophyll fluorescence variables, we notice that the vector corresponding to Fo had a positive score, being strongly related to the evaluation times in the afternoon, with higher correlation mainly to 16:00. Furthermore, the vectors of the variables $\mathrm{Fm}, \mathrm{Fv}$ and $\mathrm{Fv} / \mathrm{Fm}$ had similar direction and directed to the first evaluation times (8:00 and 10:00) becoming opposite to Fo. This behavior confirms the results observed with univariate data reported in Figure 1, indicating that in the morning, between 8:00 and 10:00 is the best time to analyze the fluorescence parameters due to the environmental conditions make possible better response of plants.

\section{Fruit yield}

The fruit weight increased linearly with the increase of irrigation replacement levels. With application of $133 \%$ of ETo (1032 $\mathrm{mm} \mathrm{yr}^{-1}$ ) there was increments of $22 \%$ in fruit mass compared to values found in lower water replacement 33\% ETo (256 $\mathrm{mm} \mathrm{yr}^{-1}$ ) (Figure 3A). The largest water availability and appropriate soil moisture allows water suitable requirement to plants, contributing to better nutrient availability, higher photosynthetic activity with intense gain assimilates and thus increased cell division, which enables maximum fruit development (Suassuna et al., 2011a). 
A.

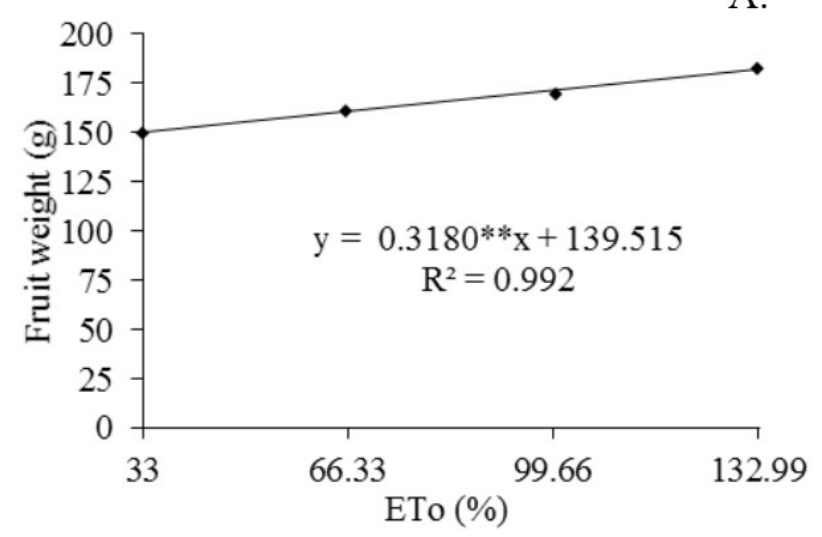

FIGURE 3. Fruit weight (CV: 7\%) (A) and fruit yield (CV: 16\%) water replacement rates.

Carvalho et al. (2000) studied the productive response of passion fruit to water replacement in rates of 25 $125 \%$ of ETo. The researchers found fruit with $161 \mathrm{~g}$ applying $90 \%$ of ETo, being evidenced reduction in size and fruit weight when they provided rates higher than that. Results mentioned in this study were similar to those obtained by Suassuna et al. (2011b), that showed better development of passion fruit IAC 273/277 when the water replacement was $120 \%$ of ETo, with fruit mass around $180 \mathrm{~g}$. The consumer prefers large fruit, good-looking fruits, free from injuries and weighing more than $170 \mathrm{~g}$ (Cavichioli et al., 2008), and these characteristics achieved in greater proportion with replacement of $133 \%$ of ETo.

Regarding to fruit yield, it is showed a quadratic adjustment of the data increasing the fruit productivity up to estimated replacement of $95.6 \%$ of ETo, which provided the maximum yield of $11.9 \mathrm{~kg} \mathrm{plant}^{-1}$ (Figure 3B). In relation to plants irrigated with maximum water replacement $(133 \%$ of ETo), there was reduction around $10 \%$ on the yield compared to the plants at $95.6 \%$ of ETo. These results were below those of the first year of cultivation, maybe due to the high number of aborted flowers due to both high temperatures (Table 1), which decrease soil moisture, as well as the small number of pollinating insects (bumblebees) present in the orchard. Productivity higher than those found were reported by Hafle et al. (2009) that obtained $16.9 \mathrm{~kg}$ plant $^{-1}$ in orchards with a year of
B.

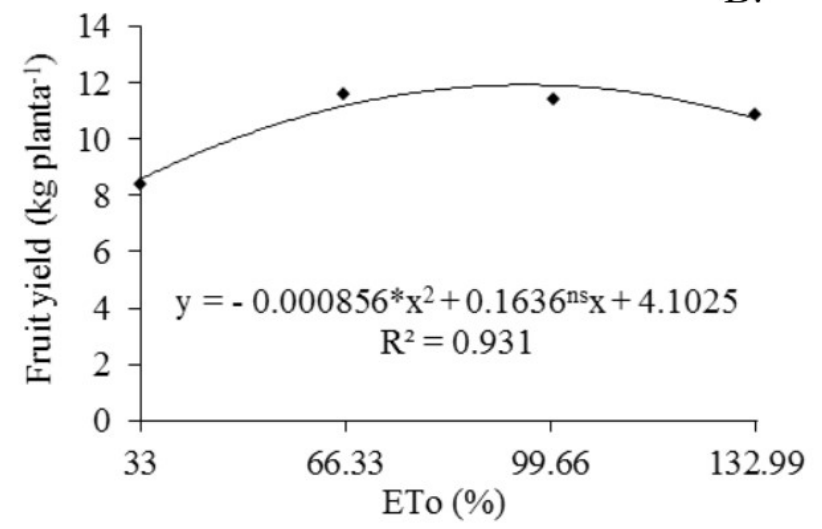

(B) of passion fruit hybrid 'BRS Gigante Amarelo' under implementation. Moreover, Suassuna et al. (2011b) reported $9.8 \mathrm{~kg} \mathrm{plant}^{-1}$ with $140 \%$ of ETo, being lower than the results observed in this study. Still, in the first year of cultivation, Araújo Neto et al. (2005) found productivity of $11.2 \mathrm{~kg} \mathrm{plant}^{-1}$ in an orchard with a density of 830 plants per hectare without pruning of tertiary branches.

\section{Fruit quality}

In the longitudinal fruit diameter (LFD) and transverse fruit diameter (TFD), the data were adjusted to quadratic models showing increase values up to the maximum water replacement estimated in 98 and $97 \%$ of ETo, respectively. It was obtained estimated values of 82 $\mathrm{mm}$ (LFD) and $76 \mathrm{~mm}$ (TFD) (Figures 4A and 4B). The soil water availability increases the direction of assimilates to the fruits, contributing to their more defined growth and development. However, it is noteworthy that the water surplus causes disruption of the cell walls, causing physical appearance of cracks on the outside of the fruit. It is noteworthy that these physical characteristics contribute both in the selection of fruit for the processed market, as it is also used in nature in the market, given the tendency of consumers to opt for bigger fruits, looking-good and undamaged in its conformation, which characterizes the main quality attribute physically examined (Cavichioli et al., 2008; Aguiar et al., 2015). 
A.
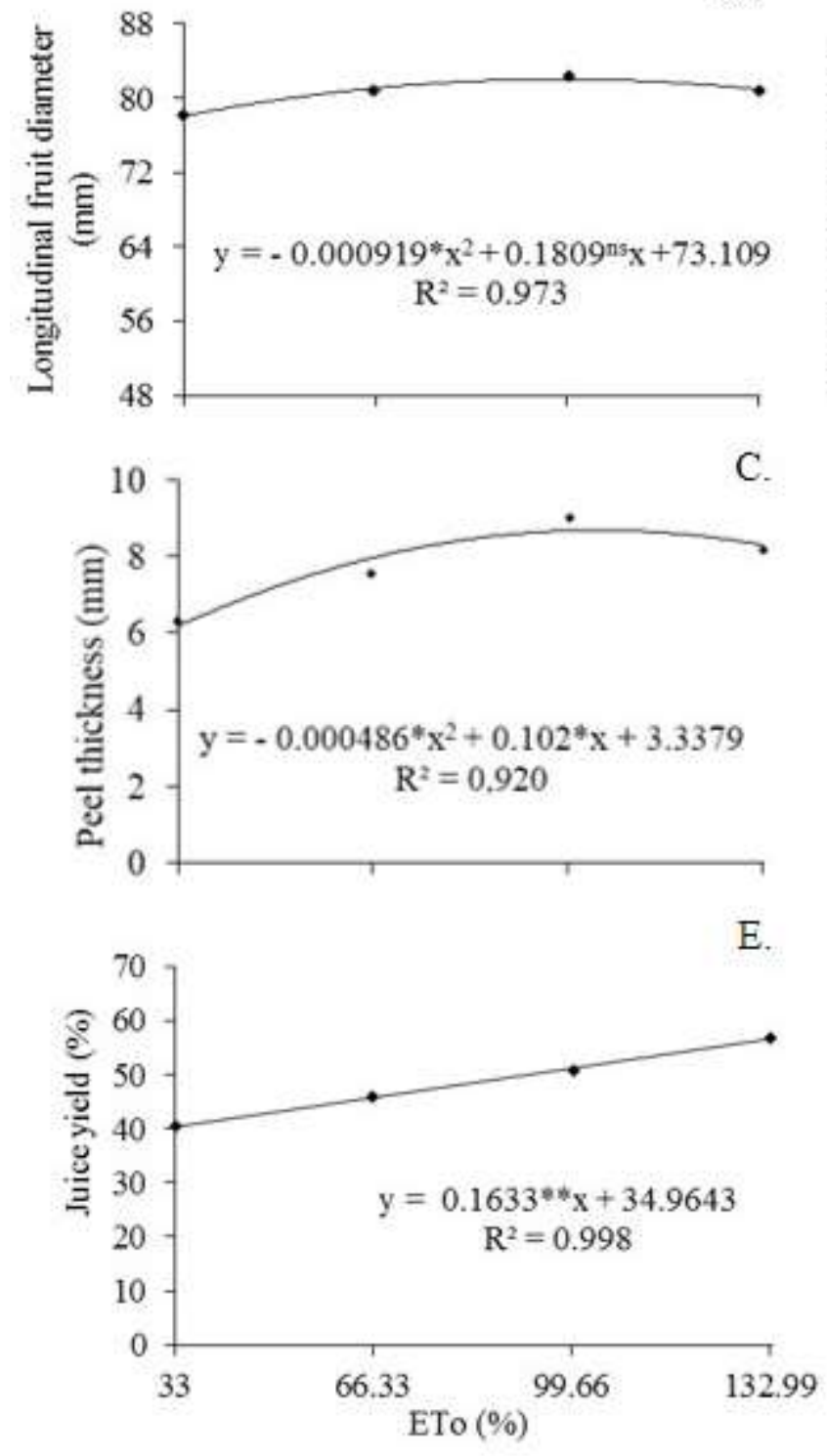

B.
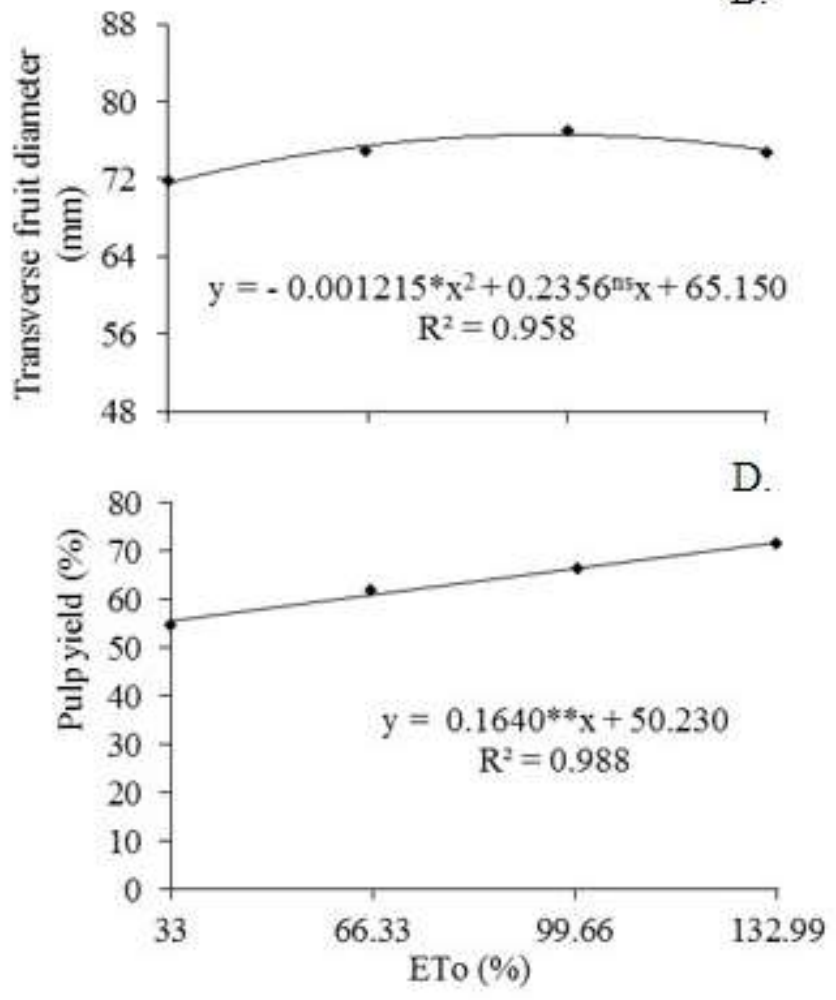

FIGURE 4. Longitudinal fruit diameter (CV: 3.5\%) (A) and transverse fruit diameter (CV: 7.7\%) (B), peel thickness (CV: 18\%) (C), pulp yield (CV: 7.3\%) (D) and juice yield (CV: 2.1\%) (E) of passion fruit hybrid 'BRS Gigante Amarelo' under water replacement rates.

Regardless of ETo rate applied, all fruits showed higher diameters of $55 \mathrm{~mm}$, the minimum required to be classified as commercial (Chagas et al., 2016). The results were superior to those mentioned by Cavichioli et al. (2008) studying irrigated passion fruit in artificial lighting conditions, finding $77 \mathrm{~mm}$ for LFD and $69 \mathrm{~mm}$ TFD. Still, assessing qualitative characteristics of hybrid yellow passion fruit, Melo et al. (2014) and Aguiar et al. (2015) found LFD 76-92 mm and TFD between 64 and $84 \mathrm{~mm}$.

By analyzing the thickness of the fruit peel (PT), another important physical characteristic, was explained by quadratic function as it increased the replacement of irrigation observing the maximum thickness of $8.7 \mathrm{~mm}$ with an estimate of $105 \%$ of ETo (Figure 4C). Fruits with thick peel reduce the pulp yield, but have higher physical resistance to transport, especially over long distances, increasing the shelf fruits life. However, studies are needed to define a default of this feature that incorporates a larger fruit of internal cavity with good pulp yield, without this meaning a greater physical damage to the fruit due to low mesocarp resistance.
The pulp yield increased linearly $(55-72 \%)$ as a function of the irrigation levels replacement. There was difference of $31 \%$ in income values between the lowest and highest irrigation levels (Figure 4D). This results are above $50 \%$ yield required by the processed market, with fruits suitable for consumption in natura and for industry (Chagas et al., 2016; Silva et al., 2016a). However, this increase in pulp yield may be related to the reduction in peel thickness occurred with water replacement rates above $100 \%$ of ETo. This fact was noted by Suassuna et al. (2011b) that highlight the importance of peel thickness in passion fruit, because the thinner the peel, the higher the fruit pulp yield. These authors found pulp yield around 54 and $63 \%$, respectively, when the plants were submitted to replacement of irrigation by 70 and $60 \%$ of ETo.

Similar behavior to pulp yield was observed in juice yield, noting that the highest level of water replacement, yield of $57 \%$ of juice, which represented an increase of $41 \%$ compared to the value obtained in the replacement of $33 \%$ 
of ETo (Figure 4E). These values were high and fit the demands of the processing industry and in nature market. There is some correlation between the reduction in peel thickness and the increase in juice yield when water levels are high, a fact related to the high fruit weight and pulp yield. The reported results were similar to those obtained by Suassuna et al. (2011b) which maximum juice yield (67\%) with application of $138 \%$ of ETo. On the other hand, the values obtained by Cavichioli et al. (2008) (35\%) were lower than in this study.

\section{Multivariate analysis}

Multivariate analysis of main components performed with all the study variables showed how the drought affected jointly the plant's characteristics. 97.34\% of the variability of the original data was contained in the first two components of the replacement rates of ETo and variable production, fruit quality (FW, FY, PT, LFD, TFD, $\mathrm{PY}$ and JY) and photochemical efficiency at 10:00 (Fo, Fm, Fv and Fv/Fm) (Figure 5).

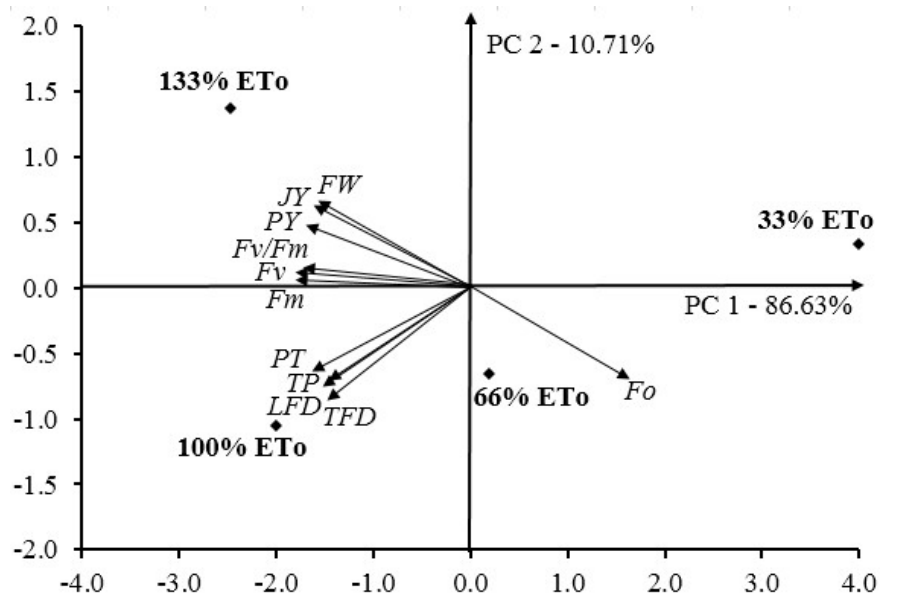

FIGURE 5. Analysis of the first two principal components associated with fruit yield (FY), fruit weight (FW), peel thickness (PT), longitudinal fruit diameter (LFD) and transverse fruit diameter (TFD), pulp yield (PY) and juice yield (JY), initial fluorescence (Fo), maximum fluorescence (Fm), variable fluorescence (Fv) and photochemical efficiency of FS II (Fv/Fm) of passion fruit hybrid 'BRS Gigante Amarelo' under different replacement rates of irrigation. The percentages correspond to the amount of variability that is explained by the respective component. The proximity of the vectors indicates a strong correlation between the variables.

The first principal component (PC1) accounted for $86.63 \%$ of the information in the original data being associated with treatment with replacement of $33 \%$ of ETo and all variables. The second principal component (PC2) is more associated with other water replacement levels with participation of $10.71 \%$ of the total variability. All PC1 eigenvectors had high negative scores for all variables, which are more strongly associated with the rate of 100 and $133 \%$ of ETo. Only Fo had a positive score being more associated with the rate of $33 \%$ of ETo.

\section{CONCLUSIONS}

The photochemical efficiency of photosystem II in passion fruit "BRS Gigante Amarelo" is changed at times with high temperatures with evidence of damage to the PHS II.

The highest production rates were achieved with irrigation level estimated of $100 \%$ of ETo (estimated at 620

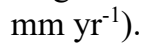

Irrigation base on water replacement of $133 \%$ of ETo promote the best fruit quality indices.

\section{ACKNOWLEDGEMENTS}

The authors are grateful to CNPq and Universidade Estadual da Paraíba for the financial support.

\section{REFERENCES}

Aguiar RS, Zaccheo PVC, Stenzel NMC, Sera T, Neves CSVJ (2015) Produção e qualidade de frutos híbridos de maracujazeiro-amarelo no norte do Paraná. Revista Brasileira de Fruticultura 37(1):130-137. DOI: http://dx.doi.org/10.1590/0100-2945-012/14

Araújo Neto SE, Ramos JD, Andrade Júnior VC, Rufini JCM, Mendonça V, Oliveira TK (2005) Adensamento, desbaste e análise econômica na produção do maracujazeiro-amarelo. Revista Brasileira de Fruticultura 27(3):394-398. DOI: http://dx.doi.org/10.1590/S010029452005000300014

Brestic M, Zivcak M, Kalaji HM, Carpentier R, Allakhverdiev SI (2012) Photosystem II thermostability in situ: Environmentally induced acclimation and genotypespecific reactions in Triticum aestivum L. Plant Physiology and Biochemistry 57:93-105. DOI: https://doi.org/10.1016/j.plaphy.2012.05.012

Brito MEB, Melo AS, Lustosa JPO, Rocha MB, Viégas PRA, Holanda FSR (2005) Rendimento e qualidade da fruta do maracujazeiro amarelo adubado com potássio, esterco de frango e de ovino. Revista Brasileira de Fruticultura 27(2):260-263. DOI: http://dx.doi.org/10.1590/S0100-29452005000200018 
Carvalho AJC, Martins DP, Monnerat PH, Bernardo S (2000) Adubação nitrogenada e irrigação no maracujazeiro amarelo. I Produtividade e qualidade dos frutos. Pesquisa Agropecuária Brasileira 35(6):1101-1108. DOI:

http://dx.doi.org/10.1590/S0100-204X2000000600005

Cavichioli JC, Ruggiero C, Volpe CA (2008) Caracterização físico-química de frutos de Maracujazeiro-amarelo submetidos à iluminação artificial, Irrigação e sombreamento. Revista Brasileira de Fruticultura 30(3):649-656. DOI: http://dx.doi.org/10.1590/S0100-29452008000300015

Chagas K, Alexandre RS, Schmildt ER, Bruckner CH, Faleiro FG (2016) Divergência genética em genótipos de maracujazeiro azedo, om base em características físicas e químicas dos frutos. Revista Ciência Agronômica 47(3):524531. DOI: http://dx.doi.org/10.5935/1806-6690.20160063

Fan X, Zhang Z, Gao H, Yang C, Lin M, Li Y, Li P (2014) Photoinhibition-like damage to the induced by submergence treatatment in the dark. Plos One 9(2):1-10. DOI:

http://doi.org/journal.pone.0089067

Freire JLO, Cavalcante LF, Rebequi AM, Dias TJ, Brehm MAS, Santos JB (2014) Quality of yellow passion fruit juice with cultivation using different organic sources and saline water. Idesia 32(1):79-87. DOI: http://doi.org/10.4067/s071834292014000100009

Hafle OM, Ramos JD, Lima LCO, Ferreira EA, Melo PC (2009) Produtividade e qualidade de frutos do maracujazeiroamarelo submetido à poda de ramos produtivos. Revista brasileira de Fruticultura 31(3): 763-770. DOI: http://dx.doi.org/10.1590/S0100-29452009000300020

IBGE - Instituto Brasileiro de Geografia e Estatística (2014) Dados de agricultura. Available in:

http://www.sidra.ibge.gov.br/

bda/tabela/protabl.asp? $\mathrm{c}=1613 \& \mathrm{z}=\mathrm{t} \& \mathrm{o}=11 \& \mathrm{i}=\mathrm{P}$. Accessed: Jul 25, 2016.

Lin Z, Zhong Q, Chen C, Ruan Q, Chen Z, You X (2016) Carbon dioxide assimilation and photosynthetic electron transport of tea leaves under nitrogen deficiency. Botanical Studies an International Journal 57(37):1-12.

DOI: http://dx.doi.org/10.1186/s40529-016-0152-8

Mantovani EC, Bernerdo S, Palaretti LF (2006) Irrigação: princípios e métodos. Viçosa, Editora UFV, 318 p.

Mathur S, Agrawal D, Jajoo A (2014) Photosynthesis: Response to high temperature stress. Journal of Photochemistry and Photobiology B: Biology 137(8): 116126. DOI: https://doi.org/10.1016/j.jphotobiol.2014.01.010

Melo AS, Suassuna JF, Fernandes PD, Brito MEB, Suassuna AF, Aguiar Netto AO (2010) Crescimento vegetativo, resistência estomática, eficiência fotossintética e rendimento do fruto da melancieira em diferentes níveis de água. Acta Scientiarum Agronomy 32(1):73-79.

Melo AS, Silva JM, Fernandes PD, Dutra AF, Brito MEB, Silva FG (2014) Gas exchange and fruit yield of yellow passionfruit genotypes irrigated with different of ETo replacement. Bioscience Journal 30(supplement 1):293-302.

Murchie EH, Lawson T (2013) Chlorophyll fluorescence analysis: a guide to good practive ande under standing some new applications. Journal Experimental Botany 64(13):39833998. DOI: https://doi.org/10.1093/jxb/ert208
Nascimento JAM, Cavalcante LF, Dantas SAG, Medeiros SA, Dias TJ (2015) Biofertilizante e adubação mineral na qualidade de frutos de maracujazeiro irrigado com água salina. Irriga 20(2):220-232.

Paula SM, Naves ER, Franco IM, Padua KJM, Silva KR, Fernandes WP, Oliveira DC, Lemos-Filho JP, Moreira ASFP (2015) Desempenho fotossintético de folhas jovens e maduras de Vochysia cinnamomea (Vochysiaceae) em áreas de cerrado rupestre intactas e pós-queimada. Bioscience Journal 31(2):591-600. DOI: http://dx.doi.org/10.14393/BJv31n2a2015-23474

Santos HG, Jacomine PKT, Anjos LHC, Oliveira VA, Lumbreras JF, Coelho MR, Oliveira JB, Cunha TJF (2013) Sistema brasileiro de classificação de solos. Rio de Janeiro, Embrapa Solos, 3 ed. 353 p.

Silva FG, Dutra WF, Oliveira MI, Dutra AF, Filgueiras LMB, Melo, AS (2015) Trocas gasosas e fluorescência a clorofila em plantas de berinjela sob lâminas de irrigação. Revista Brasileira de Engenharia Agrícola e Ambiental 19(100):946952. DOI: http://dx.doi.org/10.1590/1807-

1929/agrimabi.v19n10p946-952

Silva JM, Melo AS, Dutra AF, Suassuna JF, Dutra WF, Meneses CHSG, Viégas PRA (2016a) Profilability of yellow passion fruit as a function of irrigation depths under semiarid onditions. African Journal of Agricultural Research 11(12):1079-1085. DOI: http://dx.doi.org/10.5897/AJAR2015.10586

Silva EC, Prado TB, Alcântara RN, Silva Júnior CD, Nogueira LC (2016b) Different levels of drought stress induces changes in growth pattern but not in chlorophyll fluorescence and water relations of Hancornia speciosa Gomes seedlings. Scientia Plena 12(2):01-13.

Silva JR, Patterson AE, Rodrigues WP, Campostrini E, Griffin KL (2017) Photosynthetic aclimation to elevated $\mathrm{CO}_{2}$ combinet with partial rootzone drying results in improved water use efficiency drought tolerante and leaf carbono balance of grapevines (Vitis labrusca). Environmental and Experiental Botany 134(2):82-95. DOI:

https://doi.org/10.1016/j.envexpbot.2016.11.007

Suassuna JF, Melo AS, Costa FS, Fernandes PD, Ferreira RS, Sousa MSS (2011a) Eficiência fotoquímica e produtividade de frutos de meloeiro cultivado sob diferentes lâminas de irrigação. Semina: Ciências Agrárias 32(4):1251-1262. DOI: https://doi.org/10.5433/1679-0359.2011v32n4p1251

Suassuna JF, Melo AS, Ferraz RLS, Pereira VM, Sousa MSS (2011b) Rendimento e qualidade da produção de híbrido de maracujazeiro-amarelo 'IAC 273/277' sob diferentes níveis de irrigação. Revista Caatinga 24(4):115-122.

Thornthwaite CW (1948) An approach towards a rational classification of climate. Geographical Review 38(1):55-94.

Yamamoto Y (2016) Quality control of photosystem II: the mechanisms for avoidance and tolerance of hight and head stresses are closely linked to membrane fluidity of the thylakoids. Frontiers in Plant Science 7(1136):1-13. DOI: https://doi.org/10.3389/fpls2016.01136 